\title{
Plant- and stand-level variation in biophysical and physiological traits along tree density gradients in the Cerrado
}

\author{
Fabian G. Scholz ${ }^{1,2 *}$, Sandra J. Bucci ${ }^{1,2}$, Guillermo Goldsteinn ${ }^{2,3,4}$, Frederick C. Meinzer ${ }^{5}$, Augusto \\ C. Franco ${ }^{6}$, Ana Salazar ${ }^{4}$
}

${ }^{1}$ Departamento de Biologia, Facultad de Ciencias Naturales, Universidad Nacional de la Patagonia San Juan Bosco, (9000) Comodoro Rivadavia, Argentina. ${ }^{2}$ Comisión Nacional de Investigaciones Científicas y Técnicas (CONICET). ${ }^{3}$ Facultad de Ciencias Exactas y Naturales, Universidad de Buenos Aires, Ciudad Autónoma de Buenos Aires, Argentina. ${ }^{4}$ Department of Biology, University of Miami, P.O. Box 249118, Coral Gables, Florida 33124, USA. ${ }^{5}$ USDA Forest Service, Forestry Sciences Laboratory, 3200 SW Jefferson Way, Corvallis, Oregon 97331 USA. ${ }^{6}$ Departamento de Botanica, Universidade de Brasília, Caixa Postal 04457 Brasília, DF 70904-970 Brazil. *Corresponding author: fgscholz@unpata.edu.ar

Received: 4 September 2008; Accepted: 18 November 2008

The objective of this study was to characterize and understand morphological and physiological variation in traits related to water economy, at the plant and stand level, along a gradient of tree density in a Neotropical savanna (Cerrado). Cerrado plots subjected to long-term fertilization and gallery forests were also included in the analysis to expand the axes of ecosystem variation. Consistent changes in stand level biophysical traits observed along the gradient of increasing tree density included a decrease in weighted-average wood density, and increases in leaf surface area per plant, leaf specific hydraulic conductivity, specific leaf area and stomatal conductance. A conceptual model of biophysical, morphological and physiological trait interactions was developed in an attempt to explain determinants of hydraulic architecture and variations in water economy of Cerrado trees. Consistent with the model minimum leaf water potentials were higher, during the dry season, in low wood density trees compared to high wood density trees, and higher leaf water potential was associated with higher stomatal conductance. On the other hand, variations in stand level physiological and morphological traits along the tree density gradient could not be explained by variations in single environmental factors. Some of the potential contributing factors are: higher concentration and availability of soil nutrients in the upper portion of the gradient where tree density is greatest and constrains to tree establishment and growth by waterlogging and presence of concretions in the soil profile where tree density is lowest. Key words: gallery forest, hydraulic architecture, nutrients, savannas, specific leaf area, wood density

Variações em atributos biofísicos e fisiológicos em nível de individuo e de parcela ao longo de um gradiente de densidade arbórea no Cerrado: O objetivo deste estudo foi caracterizar e compreender as variações morfológicas e fisiológicas em atributos relacionados à economia da água, em nível de indivíduo e de parcela, que ocorrem ao longo de um gradiente de densidade arbórea em uma savana neotropical (cerrado). Parcelas de vegetação de cerrado submetidas a um experimento de adubação de longo prazo e matas de galeria também foram incluídas na análise, a fim de expandir os eixos de variação do ecossistema. Mudanças consistentes em atributos biofísicos em nível de parcela foram observadas ao longo do gradiente de densidade crescente de árvores. Estas incluíram uma diminuição na densidade média ponderada da madeira, aumentos na área foliar por planta, na condutividade hidráulica específica da folha, na área foliar específica e na condutância estomática. Um modelo conceitual das interações entre as características biofísicas, morfológicas e fisiológicas foi desenvolvido em uma tentativa de explicar os determinantes da arquitetura hidráulica e variações na economia de água de árvores do Cerrado. Consistente com o modelo, os valores mínimos de potencial 
hídrico durante a estação seca foram maiores nas árvores de baixa densidade de madeira, em comparação com árvores de alta densidade de madeira, enquanto os maiores valores de potencial hídrico foliar estiveram associados com maior condutância estomática. Por outro lado, ao longo do gradiente de densidade arbórea, as variações em nível de parcela das características morfológicas e fisiológicas não puderam ser explicadas por variações de um único fator ambiental. Alguns dos fatores contribuintes potenciais são: maior concentração e disponibilidade de nutrientes do solo na porção superior do gradiente de densidade arbórea onde há um maior número de árvores e restrições no estabelecimento e crescimento pela inundação periódica e pela presença de concreções no perfil do solo onde a densidade de árvores é mais baixa.

Palavras-chave: área foliar específica, arquitetura hidráulica, densidade da madeira, matas de galeria, nutrientes, savanas

\section{INTRODUCTION}

Determinants of water status in woody savanna plants include environmental factors as well as morphofunctional traits. Several studies have characterized the effects of seasonal changes in soil water availability and evaporative demand on regulation of leaf water status in woody plants from tropical savannas and other tropical and subtropical habitats (e.g. Eamus and Cole, 1997; Duff et al., 1997; Myers et al., 1997; Franco, 1998; Meinzer et al., 1999; Thomas and Eamus, 2002; McClenahan et al., 2004; Prado et al., 2004; Bucci et al., 2005). Fewer studies have focused on characterizing biophysical properties governing functional traits related to tree hydraulic architecture (e.g. Bucci et al., 2004; Scholz et al., 2007, 2008a). Most studies have addressed the impact of one or a few variables at a time on a particular response variable, such as the effect of wood density on leaf specific conductivity (Stratton et al., 2000; Bucci et al., 2004; Santiago et al., 2004; Choat et al., 2005), minimum leaf water potential on embolism formation (Bucci et al., 2003), root xylem vulnerability to cavitation on stomatal conductance (Domec et al., 2006) and xylem hydraulic capacitance on water transport and minimum daily leaf water potential (Meinzer et al., 2003; Scholz et al., 2007). However, studies incorporating simultaneous interactions among multiple variables in multi-species systems are scarce because of methodological difficulties associated with the rarity of steady state conditions in the field.

The savannas of central Brazil (Cerrado) show consistent changes in tree density along shallow topographic gradients of a few hundred meters in length. Vegetation structure varies from open savannas with relatively few trees in the lower portions of the topographic gradient (campo sujo) to woodlands with a relatively high density of trees in the upper portions of the gradient (cerradão). Herbaceous plant abundance follows the opposite trend, with higher coverage in open savannas to very low coverage in closed savannas (Hoffmann et al., 2005a). In the present study we characterize plant- and stand-level variations in tree morpho-physiological traits related to water economy along gradients of Cerrado ecosystem structure. To expand the range of ecosystem variation, we include in the gradient gallery forest stands which occur in Cerrado domain, adjacent to our study sites.

The reasons why no forest with a continuous canopy develops in the Brazilian savanna region are still debated (Hoffmann et al., 2005b; Silva et al., 2008). The possible explanations include climatic, edaphic, and anthropogenic factors (e.g. Sarmiento, 1984; Ribeiro and Walter, 1998). Among the edaphic reasons, the short supply of almost all plant nutrients, and in particular low $\mathrm{N}$ and $\mathrm{P}$ levels (Haridasan, 2001; Bucci et al., 2006; Bustamante et al., 2006; Kozovits et al., 2007), may be one of the major factors limiting tree growth and development of a multi-layered forest canopy (Sarmiento, 1984). The association of savanna vegetation with dystrophic soils in the Neotropics has long been established (e.g. Sarmiento, 1983; Furley and Ratter, 1988). Within the same geographical area of distribution and under similar climatic conditions deciduous forests are found on soils characterized by higher Ca content and good fertility (Ratter et al., 1978). These forests are floristically and structurally similar to dry forests found elsewhere in the Caatinga, on eastern slopes of the Andes, Central America, as well as in Ca rich soils within the Cerrado region.

Cerrado oxisol soils, typical of the Cerrado are very nutrient deficient, their $\mathrm{pH}$ and cation exchange capacities are very low, and their aluminum saturation levels 
are high (Furley and Ratter, 1988; Furley, 1999; Haridasan, 2000). Even though standard nutrient content analyses of soils along the tree density gradient do not show substantial changes in most of their chemical characteristics, there is still some reason to think that nutrient availability may play an important role in driving Cerrado ecosystem changes and tree growth patterns in space and time. Long-term fertilization with $\mathrm{N}$ and $\mathrm{P}$ in Cerrado sites with intermediate tree density, cerrado sensu stricto, resulted in pronounced changes in total leaf surface area per plant, hydraulic architecture traits and leaf water status and key attributes related with nutrient cycling (Bucci et al., 2006; Kozovits et al., 2007). To further expand the axes of ecosystem variation in the present study, we used data from these fertilized plots as well.

Even if strong correlations are observed among traits, they may not necessarily be indicative of cause-effect relationships. It is difficult to detect the mechanisms underlying correlations among traits by using a large group of interacting variables, unless a conceptual framework exists and carefully selected scaling variables are used. The key biophysical and morphological scaling variables employed in this study of determinants of water relations of woody savanna plants were: wood density (density of active xylem), total leaf surface area per plant, and specific leaf area. These three variables are expected to constrain important aspects of the hydraulic architecture of trees, their growth rate and regulation of water balance. Biophysical characteristics of the active xylem and wood density in particular, are expected to constrain plant water balance via their impact on stem hydraulic conductivity and capacitance. Stem conductivity and total leaf surface area influence leafspecific hydraulic conductivity, a major determinant of leaf gas exchange capacity. Specific leaf area reflects properties of leaves as they are impacted by leaf water status and photosynthetic capacity (Reich et al., 1997, 1999; Shipley et al., 2005). To avoid the potential pitfalls of using correlations between scaling variables as indicators of causation, we established an a priori network of cause and effect relationships between biophysical, morphological and physiological traits of Neotropical savanna woody plants. These relationships were used to develop a model identifying the main determinants of the hydraulic architecture and water economy for Cerrado trees.

\section{MATERIAL AND METHODS}

Study site: The study was carried out at the Instituto Brasileiro de Geografia e Estatistica (IBGE) Ecological Reserve, a field experimental station located $33 \mathrm{~km}$ south of Brasilia, Brazil (lat. 15 56', lon 47 53' W, alt. $1100 \mathrm{~m}$ ). The IBGE includes extensive areas of all major physiognomies of Cerrado vegetation from open to closed savannas, including evergreen gallery forest. Annual precipitation in the reserve ranges from 880 to $2150 \mathrm{~mm}$ with a mean of approximately $1500 \mathrm{~mm}$. There is a pronounced dry season from May through September with the months of June, July and August being nearly rainless. Mean annual temperature averages $22{ }^{\circ} \mathrm{C}$. Maximum diurnal air temperature differences can be as large as $20^{\circ} \mathrm{C}$ during a typical dry season day.

Four physiognomies along a gradient of increasing tree density (trees with stem diameter $>4-\mathrm{cm}$ at $30 \mathrm{~cm}$ above ground and height $>100-\mathrm{cm}$ ) were selected: campo sujo, cerrado sensu stricto, cerrado denso and cerradão. Campo sujo is an open savanna with scattered shrubs and few trees (960 trees ha-1), cerrado sensu stricto is typical savanna with intermediate tree density (2600 trees $\mathrm{ha}^{-1}$ ), cerrado denso is a savanna with relatively high tree density (2900 trees ha-1), and cerradão is a nearly closedcanopy savanna, or woodland (3300 trees ha-1). We also incorporated information on trees from adjacent evergreen gallery forests occurring along the Pitoco stream (1900 trees ha-1 with DAP > 5 cm; Silva Jr. 2005), as well as data from Cerrado sensu stricto plots (2700 trees $\mathrm{ha}^{-1}$ ) subjected to three long-term (5 yr) fertilization treatments (Nitrogen, Phosphorous, and Nitrogen plus Phosphorous;). Details about the fertilization experiment are described in Bucci et al., (2006).

Cerrado soils are deep oxisols with a high percentage of clay. The soils along the gradient (cerradão to campo sujo) have similar bulk density $\left(0.99 \pm 0.02 \mathrm{~g} \mathrm{~cm}^{-3}\right)$, macro porosity (17.9 $\pm 0.4 \%$ ) and texture fraction (silt/clay, 0.22 \pm 0.02 ) at 10, 20, 30, 60 and $100 \mathrm{~cm}$ depth (Bucci et al., 2008). Field capacity and micro-porosity at 30, 60 and 100 cm depth are significantly lower in the campo sujo site than in the other physiognomies with higher tree density $(\mathrm{P}<0.1)$ (Bucci et al., 2008). During the peak of the dry season in August soil water storage between 10-250 cm depth is significantly lower $(\mathrm{P}<0.01)$ in the cerradão $(200 \mathrm{~mm})$ than in the campo sujo (400 mm) (Bucci et al., 2008). 
Analyses of chemical properties of soil samples collected in campo sujo, cerrado sensu stricto and cerradão sites and performed in the soil laboratory of EMBRAPA-Cerrados indicated that all sites had similar $\mathrm{pH}$ (about 4.3), but cerradão soils down to $50 \mathrm{~cm}$ depth have higher $\mathrm{P}$ concentrations ( $\left.0.60 \mathrm{mg} \mathrm{L}^{-1}\right)$ compared to campo sujo soils (0.48 $\left.\mathrm{mg} \mathrm{L}^{-1}\right)$. Potassium and Ca levels were similar. Bustamante et al., (2004) did not find differences in $\mathrm{N}$ concentration between the surface and $100 \mathrm{~cm}$ depth among campo sujo, cerrado denso and cerradão sites. Gallery forest soils have relatively high nutrient content compared to soils in savanna physiognomies (e.g. 4.8 (pH); 11.2 (\%OM); 0.3 $(\% \mathrm{~N}) ; 4 \mathrm{mg} \mathrm{dm}^{-3}(\mathrm{P}), 0.2 \mathrm{cmol} \mathrm{dm}^{-3}(\mathrm{Ca})$ to upper layer (0100cm)) (Silva Jr., 2005; Silva et al., 2008)

Long term fertilization with $\mathrm{N}, \mathrm{P}$ and $\mathrm{N}+\mathrm{P}$ affected chemical properties of soils in the cerrado sensu stricto plots used in this study (Kozovits et al., 2007). Plots fertilized with $\mathrm{N}$ and $\mathrm{N}+\mathrm{P}$ had lower values of $\mathrm{pH}$. Available $\mathrm{P}$ concentration were enhanced $7 \cdot 3$ times in $\mathrm{N}+\mathrm{P}$ plots compared to the control plots. Although $\mathrm{N}$ and $\mathrm{N}+\mathrm{P}$ fertilizations did not alter total $\mathrm{N}$ in the soil, these treatments resulted in an increase in available inorganic $\mathrm{N}$ and $\mathrm{P}$.

Data used in this study were collected during the dry seasons of 2001 through 2004. A total of 21 tree species belonging 15 families, including five species in the gallery forest, were selected based on their abundance (Table 1). Mean basal area + SE $\left(\mathrm{cm}^{2}\right)$ per tree at each site was: $80 \pm$ 15 (cerradão), $62 \pm 7$ (cerrado denso), 393 (cerrado sensu stricto), $46 \pm 5$ (campo sujo), $40 \pm 2$ (cerrado sensu stricto fertilized with $\mathrm{N}$ ); $35 \pm 4$ (cerrado sensu stricto fertilized with P); $46 \pm 4$ (cerrado sensu stricto fertilized with $\mathrm{N}+\mathrm{P}$ ) and $124 \pm 11$ (gallery forest). Total leaf area index of shrubs and trees ranges from 0.4 in campo sujo to 2.5 in cerradão sites during the dry season and from 0.5 in campo sujo to 2.9 in cerradão sites during the wet season (Hoffmann et al., 2005a; Bucci et al., 2008).

Wood density: The density of sapwood was measured near the base of the trunk in three to six individuals of similar size per species. Samples were obtained with an increment borer, and sealed in aluminum foil and plastic bags. Density $\left(\rho_{\mathrm{w}}\right)$ was calculated as:

$$
\rho_{\mathrm{w}}=M / V
$$

Where $M$ is the mass of the sample and $V$ is the sample volume. Volume was estimated by submerging the sample in a container with distilled water resting on a digital balance with $0.001 \mathrm{~g}$ precision. The sample was kept submerged during measurements until saturation with the help of a very small needle without touching the walls of the container. To represent site-specific differences along the gradients, wood density was "weighted" by average basal area per site and species to represent sitespecific differences instead of species-specific differences. Weighted wood density was expressed as: $\left(\rho_{\mathrm{w}}{ }^{*} \mathrm{BA} \mathrm{A}_{\mathrm{l}}\right) / \mathrm{BA}_{\mathrm{T}}$ where $\mathrm{BA}_{\mathrm{i}}$ is the basal area per tree and $\mathrm{BA}_{\mathrm{T}}$ is mean basal area per site.

Specific leaf area and total leaf area per plant: Ten to 50 fully expanded sun leaves, depending on the total number of leaves per plant, were collected from three to six trees per species and site during the dry season. Fresh leaf area was determined with a scanner. Leaves were oven-dried $\left(70{ }^{\circ} \mathrm{C}\right)$ for $48 \mathrm{~h}$, and dry mass determined for calculation of leaf area per dry mass (SLA, specific leaf area). Total leaf area per plant was obtained for all sites, with the exception of gallery forest sites, by multiplying the number of leaves per plant by the average area per leaf determined from fresh leaf samples of each tree.

Hydraulic conductivity: Stem hydraulic conductivity $\left(k_{\mathrm{h}}\right)$ was measured on 5 branches per species, taken from three to five different individuals. Branches were collected early in the morning and the distal end of each branch cut under water to avoid embolism. The cut ends were kept under water and the entire branches were tightly covered with plastic bags and transported to the laboratory. Stem segments were recut again under water and attached to the hydraulic conductivity apparatus. Stem segments much longer than the maximum vessel length were used to avoid open vessels. Distilled water was used as the perfusion fluid. Relatively low hydrostatic pressure generated by a constant hydraulic head of $32 \mathrm{~cm}$ was applied to avoid refilling of embolized vessels. Hydraulic conductivity ( $\mathrm{kg} \mathrm{m} \mathrm{s}^{-1} \mathrm{MPa}^{-1}$ ) was calculated as the ratio of the flow rate through the segment $\left(\mathrm{J}_{\mathrm{v}} ; \mathrm{kg} \mathrm{s}^{-1}\right)$ and the pressure gradient across the segment $\left(\Delta \mathrm{P} / \Delta \mathrm{L} ; \mathrm{MPa} \mathrm{m}^{-1}\right)$. Sapwood conducting area $\left(A_{S}\right)$ and distal leaf area $\left(A_{L}\right)$ were measured to calculate the ratio $A_{L}$ : $A_{S}$. Specific hydraulic conductivity $\left(k_{\mathrm{s}} ; \mathrm{kg} \mathrm{m}^{-1} \mathrm{~s}^{-1} \mathrm{MPa}^{-1}\right)$ was calculated as the ratio of $k_{\mathrm{h}}$ to $\mathrm{A}_{\mathrm{S}}$ and leaf specific hydraulic conductivity $\left(k_{1} ; \mathrm{kg} \mathrm{m}^{-1} \mathrm{~s}^{-1} \mathrm{MPa}^{-1}\right)$ was calculated as the ratio of $k_{\mathrm{h}}$ to $\mathrm{A}_{\mathrm{L}}$. 
Table 1. Species used in this study, leaf phenology patterns and types of cerrado vegetation where each species was studied. Abbreviations are: BD (brevideciduous); E (evergreen); D (deciduous); cs (campo sujo); cc (campo cerrado); css (cerrado sensu stricto); cd (cerrado denso); co (cerradão), gf (gallery forest), and N (css sites fertilized with N), P (css sites fertilized with $\mathrm{P}$ ) and $\mathrm{N}+\mathrm{P}$ (css sites fertilized with $\mathrm{N}+\mathrm{P}$ ).

\begin{tabular}{|c|c|c|c|}
\hline Species & Family & Phenology & Sites \\
\hline Aspidosperma tomentosum Mart. & Apocynaceae & $\mathrm{D}$ & CS, CSS, CO \\
\hline Byrsonima crassa Nied. & Malpighiaceae & $\mathrm{BD}$ & cs, css, cd, co, N, P, N+P \\
\hline Blepharocalyx salicifolius (H.B.K.) Berg & Myrtaceae & $\mathrm{BD}$ & cs, css, cd, co, N, P, N+P \\
\hline Caryocar brasiliense Camb. & Caryocaraceae & $\mathrm{BD}$ & css, cd, N, P, N+P \\
\hline Guapira areolata (Heimer) Lundell & Nyctaginaceae & $\mathrm{BD}$ & Gf \\
\hline Guapira noxia (Netto) Lundell & Nyctaginaceae & $\overline{\mathrm{BD}}$ & CS, Css, CO, N, P, N+P \\
\hline Dalbergia miscolobium Benth. & Leguminosae & $\mathrm{BD}$ & CS, CSS, CO \\
\hline Eriotheca pubescens Schott \& Endl. & Bombacaceae & $\mathrm{BD}$ & CS, CSS, cd, CO, N, P \\
\hline Guarea guidonia (L.) Sleumer & Meliaceae & $\mathrm{E}$ & Gf \\
\hline Kielmeyera coriacea (Spr.) Mart. & Guttiferae & $\mathrm{D}$ & cS,cd \\
\hline Miconia cuspidata Naud & Melastomataceae & $\mathrm{E}$ & Gf \\
\hline Myrsine guianensis (Aubl.) Kuntze & Myrsinaceae & $\mathrm{E}$ & CS, CSS, CO \\
\hline Protium sp. Burm.f. & Burseraceae & $\mathrm{E}$ & Gf \\
\hline Ouratea hexasperma Baill. & Ochnaceae & $\mathrm{E}$ & CS, css, co, N, P, N+P \\
\hline Qualea grandiflora Mart. & Vochysiaceae & $\overline{\mathrm{D}}$ & CS, CSS, CO \\
\hline Qualea parviflora Mart. & Vochysiaceae & $\mathrm{D}$ & cs, css, cd, co, N, P, N+P \\
\hline Schefflera macrocarpa Seem & Araliaceae & $\mathrm{E}$ & cS, css, cd, co, N, P, N+P \\
\hline Schefflera morototoni (Aubl.) & Araliaceae & $\mathrm{E}$ & Gf \\
\hline Sclerolobium paniculatum Vog. & Leguminosae & $\mathrm{E}$ & cSS, css, cd \\
\hline Styrax ferrugineus Nees \& Mart. & Styracaceae & $\mathrm{E}$ & CS, cd \\
\hline Vochysia thyrsoidea Mart. & Vochysiaceae & E & cS, cd \\
\hline
\end{tabular}

Stomatal conductance: A null balance porometer (Model LI-1600, LiCor Inc., Lincoln, Nebraska, USA) was used to measure stomatal conductance $\left(g_{S}\right)$ on three to five leaves of three to six plants per species along the gradient. Typically, five to six complete sets of measurements were obtained during the course of a day. New, fully expanded leaves from sun-exposed areas of the tree crowns were used for measurements.

Leaf water potential and turgor loss point: Midday leaf water potential $\left(\Psi_{\mathrm{L}}\right)$ was measured with a pressure chamber (PMS Instruments, Corvallis OR, USA) in three exposed leaves on each of three to six individuals per species during the dry season. Turgor loss point $\left(\pi^{0}\right)$ was determined from pressure-volume relationships (Tyree and Hammel, 1972) for three, fully developed exposed leaves from three to six individuals per species.

Data analysis: The SPSS 11.5 statistical package (SPSS Inc.) was used for statistical analysis. Wood density, $\Psi_{L}, g_{S}, k_{S}$, $k_{L}, \pi^{0}$, SLA and mean total leaf area were analyzed for normal distribution using Kolmogorov-Smirnov test, and one-way ANOVA was applied to test differences in means across sites. Once it was determined that differences existed among the means, LSD test for multiple comparison was used to determine site differences. Linear regressions were fitted to relationships in Figure 2, 3, 4, 5, 6 and 8. Exponential decay relations were used in Figure 7.

\section{RESULTS}

Wood density and SLA varied across sites differing in tree density in most species (Figure 1). For species exhibiting significant variations in wood density along the tree density gradient, the pattern of variation was similar: wood density was higher in sites with low tree density. The opposite trend was observed with SLA. Most species had lower SLA (thicker leaves) in low tree density sites (Figure 1). When gallery forest and fertilized sites were included in the analysis, a consistent pattern emerged with SLA declining with increasing wood density in six species with a wide distributional range 


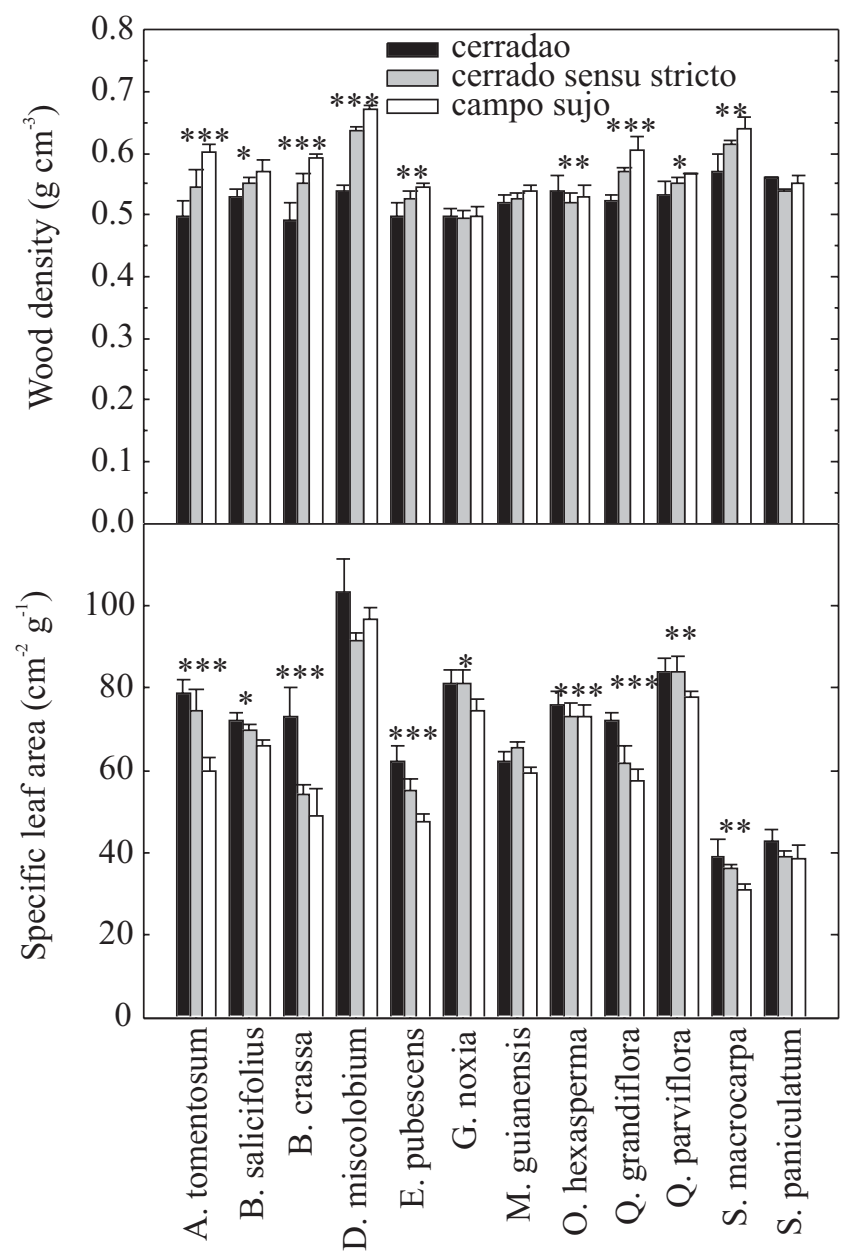

Figure 1. Wood density (a) and specific leaf area (b) for 12 tree species with wide distribution in cerradão (high tree density), cerrado sensu stricto (intermediate tree density) and campo sujo (open savanna with low tree density) at the IBGE research station. Bars are mean values + SE for 5 or 6 individuals per species. Significant differences between sites are indicated as: *** $(\mathrm{P}<0.001)$; ** $\mathrm{P}<0.01$; $\left.{ }^{*} \mathrm{P}<0.05\right)$.

(Figure 2). A strong inverse relationship $\left(\mathrm{R}^{2}=0.79 ; \mathrm{P}<0.01\right)$ was found between weighted average wood density and mean SLA across vegetation types (Figure 3). Mean weighted average values or mean values were used to represent site-specific differences instead of the speciesspecific differences shown in Figures 1 and 2. Significant differences were found across sites $(\mathrm{P}<0.01)$, with gallery forest species having the highest mean SLA and the lowest wood density, and the campo sujo species having the lowest SLA and the highest wood density. The other sites had intermediate values between the extremes.
Several scaling relationships of leaf-trait and hydraulicarchitecture variables reflecting site specific differences were identified. Weighted average wood density (a hydraulic trait) declined and mean SLA increased, with increasing mean total leaf area per plant across sites $(\mathrm{P}<0.05)$ (Figure 4). Total leaf area per plant, as we will see in the discussion section, influences the delivery of water per unit leaf surface area. Mean total leaf area per plant tended to be higher in sites where tree density was lower and specific leaf area higher. Both mean maximum stomatal conductance and mean SLA increased with increasing mean safety margin for turgor loss ( $\pi^{0}$-midday $\left.\Psi_{L}\right)$ across sites $(\mathrm{P}<0.05)$ (Figure 5). Mean maximum stomatal conductance also declined linearly with increasing weighted average site-specific wood density (Figure 6). Both mean specific and leaf specific stem hydraulic conductivity for all species decreased exponentially with increasing weighted average wood density, across sites $(\mathrm{P}<0.05)$ (Figure 7$)$. Consistent with a decrease in stem water transport efficiency with increasing wood density across sites, average midday $\Psi_{\mathrm{L}}$ for the species in a site declined from -1.1 MPa to -1.7 MPa with increasing weighted average wood density $(\mathrm{P}<0.05)$ (Figure 8).

\section{DISCUSSION}

Physiognomic variations along topographic gradients: Cerrado vegetation is characterized by a mosaic of physiognomies differing in tree density. Determinants of variations in tree density along topographic gradients have been controversial and several hypotheses been suggested to explain this important pattern of geographical variation across the Cerrado landscape. Goodland (1971) focused attention on the role of $\mathrm{Al}$ in the soil, indicating that $\mathrm{Al}$ increases toward the lower end of the topographic gradient where trees are shorter and open savanna physiognomies predominate. However, we did not find evidence of increasing $\mathrm{Al}$ in the soil down to $0.5 \mathrm{~m}$ deep in open physiognomies studied. Levels of $\mathrm{Al}$ in Cerrado soils are so high as to be extremely toxic to most agricultural plants, but are well tolerated by native Cerrado plants (Haridasan and Araujo, 1988; Haridasan, 2008). Soil moisture has been also suggested to be another factor that determines variations in physiognomies within the Cerrado landscape (OliveiraFilho et al., 1989; Ruggiero et al., 2006). Cerrado 


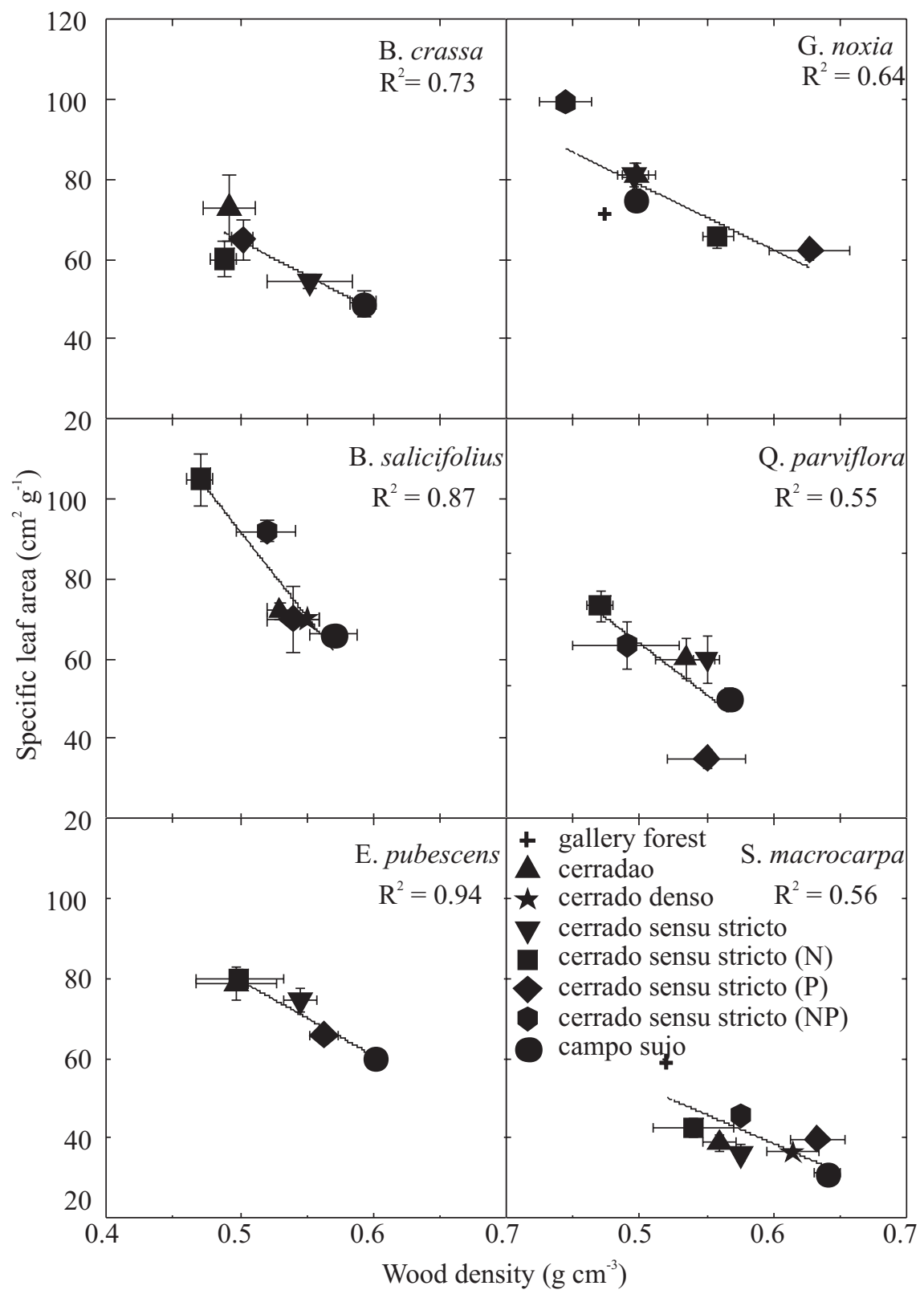

Figure 2. Specific leaf area in relation to wood density for six species growing in sites differing in tree density (cerradão, cerrado denso, cerrado sensu stricto, campo sujo sites and gallery forest) and cerrado sensu stricto sites subjected to long-term fertilization with N, P and N+P. The following species with wide distribution along the gradient were included in the figure: Byrsonima crassa, Blepharocalyx salicifolius, Eriotheca pubescens, Guapira noxia (Guapira aereolata in the gallery forest site), Qualea parviflora and Schefflera macrocarpa (Schefflera morototoni in the gallery forest site). Each symbol represents the mean value \pm SE of 3 to 6 individuals per species and per site.

physiognomies with high tree density are found on soils that are never flooded while in the lower part of the topographic gradient, open savannas tend to predominate when the drainage is impeded. It is known that the water table in these sites may be relatively close to the soil surface but a long term quantitative study of water table fluctuations has never been done and consequently it is difficult to assess the importance of water table dynamics and soil waterlogging in controlling vegetation distribution in the Cerrado. It is quite possible 


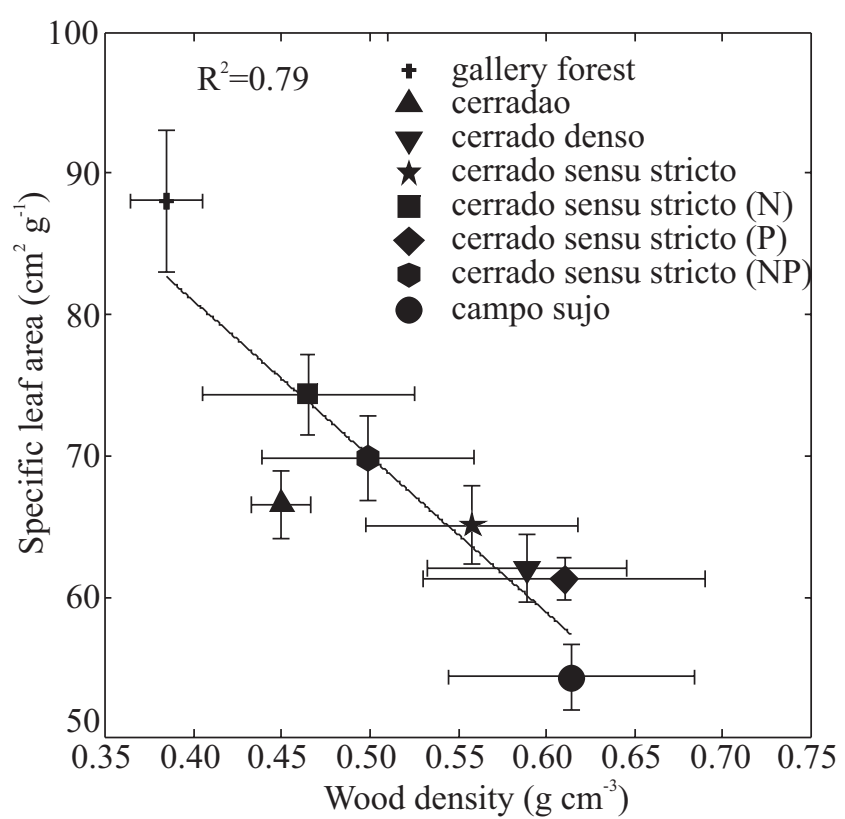

Figure 3. Specific leaf area (SLA) in relation to weighted average wood density for sites differing in tree density (cerradão, cerrado denso, cerrado sensu stricto, campo sujo and gallery forest) and cerrado sensu stricto sites subjected to long term fertilizations with $\mathrm{N}, \mathrm{P}$ and $\mathrm{N}+\mathrm{P}$. Each point represents the mean value \pm SE of 10 to 16 species per site. For the gallery forest site only five dominant species were used. The line is a linear regression fitted to the data: $\mathrm{y}=121-103 \mathrm{x} ; \mathrm{P}<0.01$ )

that saturated soil layers close to the soil surface may impair tree growth and perhaps tree seedling establishment. Joly and Crawford, (1982) have shown the inability of Cerrado tree roots to tolerate waterlogged soils. Fire has been suggested as another important factor determining tree density. The fire frequency explanation of changes along the gradients is partially tautological because the relative abundance of herbaceous vegetation in open savannas is high, resulting in higher fire frequency, and consequently in relatively low tree density (Coutinho, 1990; Moreira, 2000). Although fire is undoubtedly an important environmental driver in Cerrado vegetation, fire alone can not explain the consistent changes in tree density along topographic gradients.

The focus of this work is on environmental and morpho-functional traits of trees rather than on environmental determinants of tree density along topographic gradients. Nevertheless, some of the factors discussed above may be useful in explaining shifts in

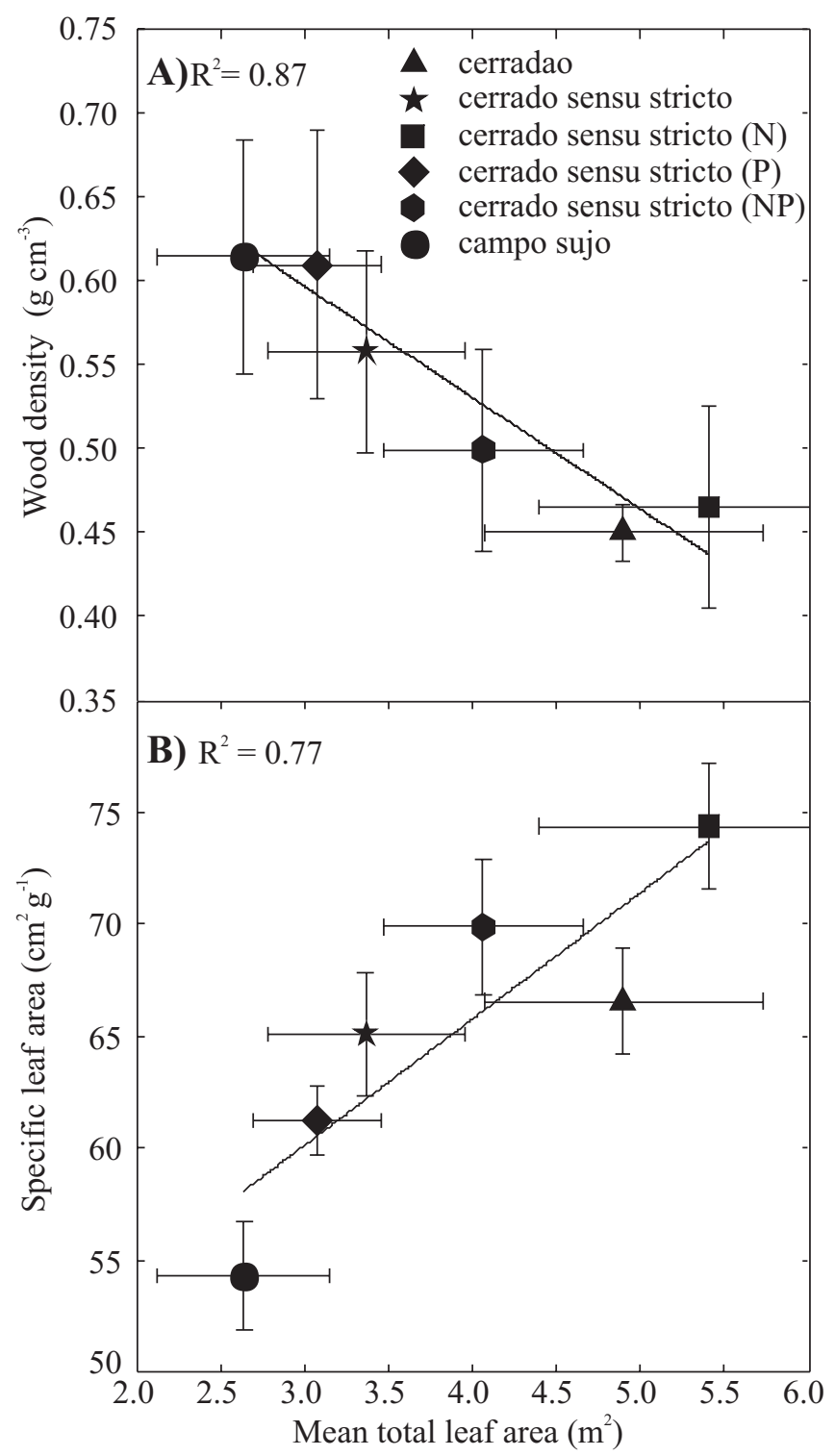

Figure 4. Weighted average wood density (a) and specific leaf area (b) in relation to average leaf area per plant across sites differing in tree density (cerradão, cerrado sensu stricto, campo sujo) and cerrado sensu stricto stands subjected to long term fertilizations with $\mathrm{N}, \mathrm{P}$ and $\mathrm{N}+\mathrm{P}$. Each point represents the mean values \pm SE of 10 to 16 tree species per site. The lines are linear regressions fitted to the data (a) $y=0.80-0.07 x$; $P<0.01$; (b) $y=43.3+5.6 x$; $\mathrm{P}<0.05$.

water economy and hydraulic architecture of trees along gradients of ecosystem structure.

Biophysical and physiological traits variation along gradients: Plant species growing together in a particular 


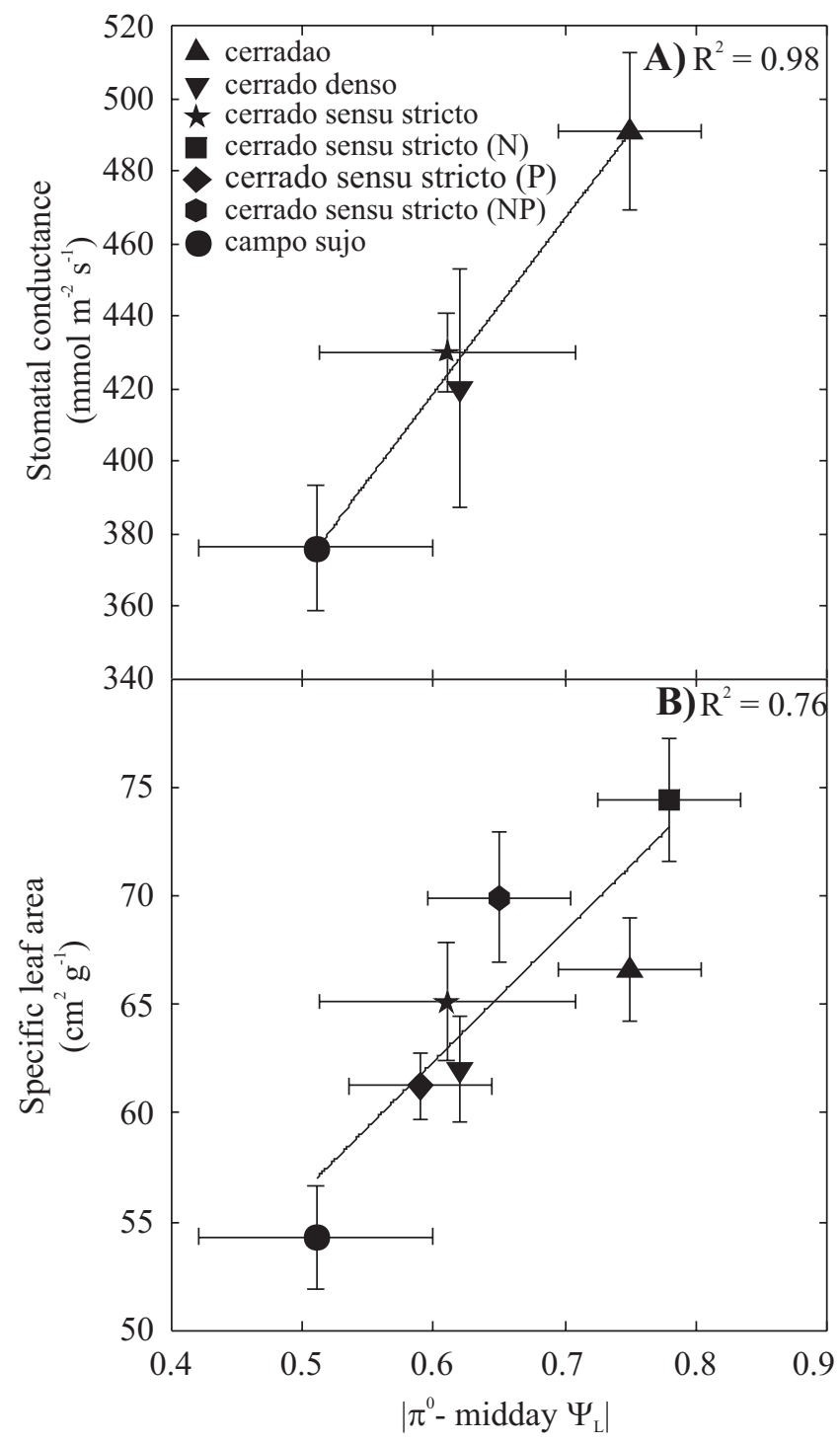

Figure 5. Mean stomatal conductance (a) and mean specific leaf area (b) in relation to mean safety margin for turgor loss $\left(\pi^{0}\right.$-midday $\left.\Psi_{\mathrm{L}}\right)$ for sites differing in tree density (cerradão, cerrado denso, cerrado sensu stricto and campo sujo) and cerrado sensu stricto sites subjected to long term fertilization with $\mathrm{N}, \mathrm{P}$ and $\mathrm{N}+\mathrm{P}$. Each point represents the mean values \pm SE of 10 to 16 tree species per site. Lines are the linear regressions fitted to the data: (a) $y=$ $130+481 x ; \mathrm{P}<0.001 ;$ (b) $\mathrm{y}=26+60 \mathrm{x} ; \mathrm{P}<0.05$.

site usually exhibit a relatively large variation in physiological and morphological characteristics. Those differences may help to reduce inter-specific competition and allow coexistence of different species in the same habitat. Despite being a stressful environment, the ensemble of tree species in Cerrado vegetation is very

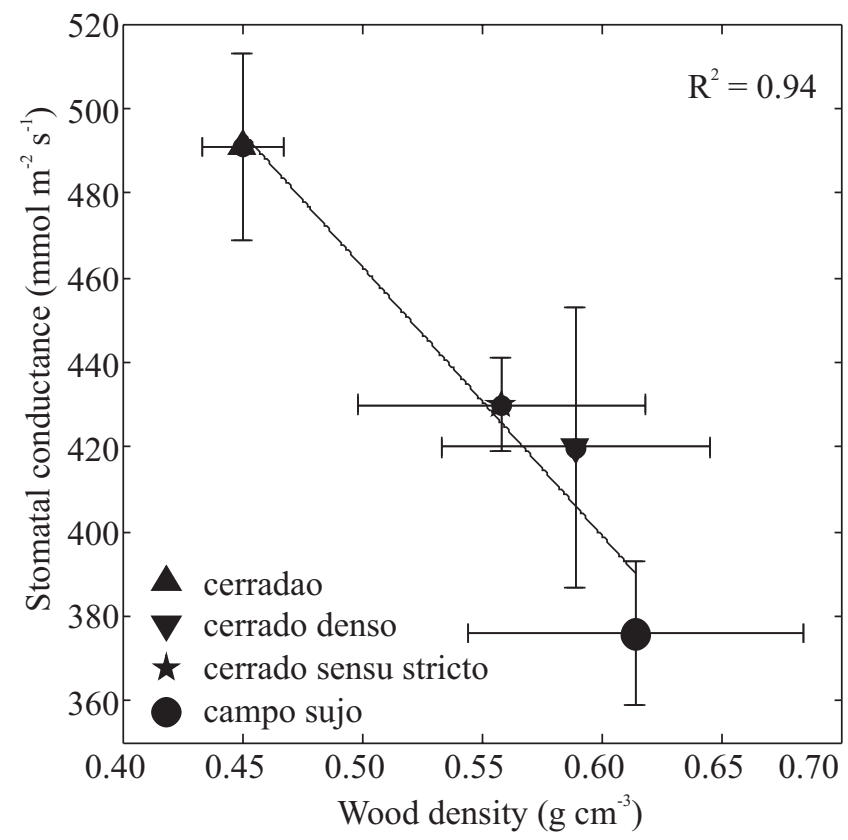

Figure 6. Stomatal conductance in relation to weighted average wood density for sites differing in tree density (cerradão, cerrado denso, cerrado sensu stricto and campo sujo). Each point represents the mean values \pm SE of 10 to 16 tree species per site. Line is the linear regression fitted to the data: $\mathrm{y}=780-634 \mathrm{x} ; \mathrm{P}<0.05$.

diverse and most of them have a wide distributional range. Consistent variations in biophysical and physiological traits were observed in dominant tree species along the gradient. For example, wood density and SLA changed in a similar fashion along the gradient in several tree species, with wood density decreasing, and SLA increasing, from open savannas (campo sujo) to high tree density savannas (cerradão) (Figure 1). Weighted average values of wood density and mean values of SLA for the dominant tree species as expected followed the same trend as the individual species. The means clearly differed along the gradient (Figure 3) despite substantial variability among species within a site. Because the individual species values and the stand level values of wood density and SLA varied following similar trends along the gradients we can assume that environmental factors are driving the observed morphofunctional changes.

Morphological and physiological traits related to the hydraulic architecture and water relations of savanna 


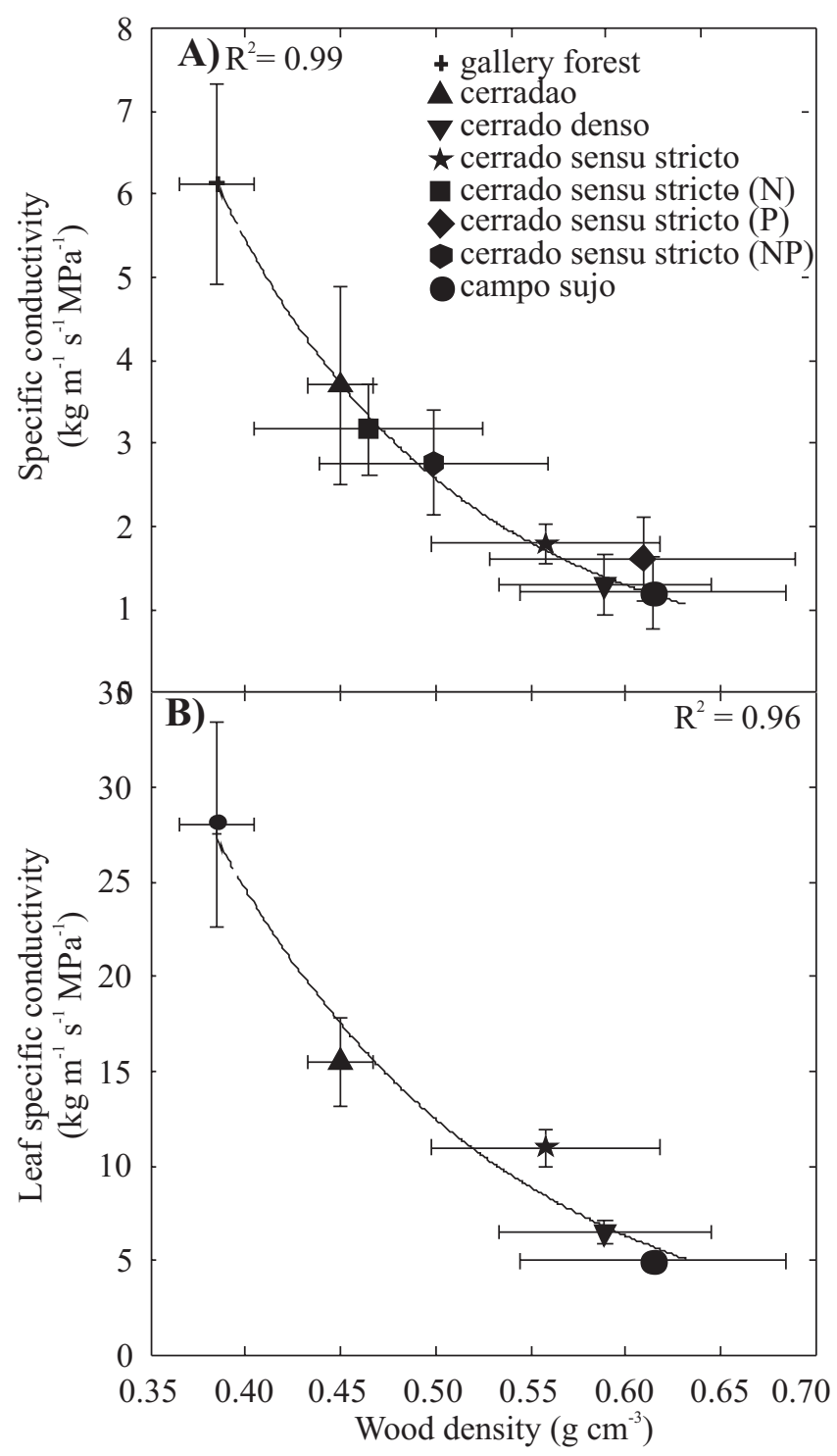

Figure 7. Specific hydraulic conductivity (a) and leaf specific hydraulic conductivity (b) in relation to weighted average wood density for sites differing in tree density (cerradão, cerrado denso, cerrado sensu stricto, campo sujo, gallery forest and cerrado sensu stricto sites subjected to long term fertilizations with $\mathrm{N}, \mathrm{P}$ and $\mathrm{N}+\mathrm{P}$. Each point represents the mean value \pm SE of 10 to 16 species per site. For the gallery forest site only five dominant species were used. The lines are the exponential decaying functions fitted to the data: (a) $y=1.06+222$ $\exp (-11 \mathrm{x}) ; \mathrm{P}<0.05$; (b) $\mathrm{y}=372 \exp (-6.8 \mathrm{x}) ; \mathrm{P}<0.001$.

trees: Several scaling variables reflecting ecosystemlevel properties were functionally related to weighted average wood density. Weighted average wood density was found to be inversely related to mean xylem specific

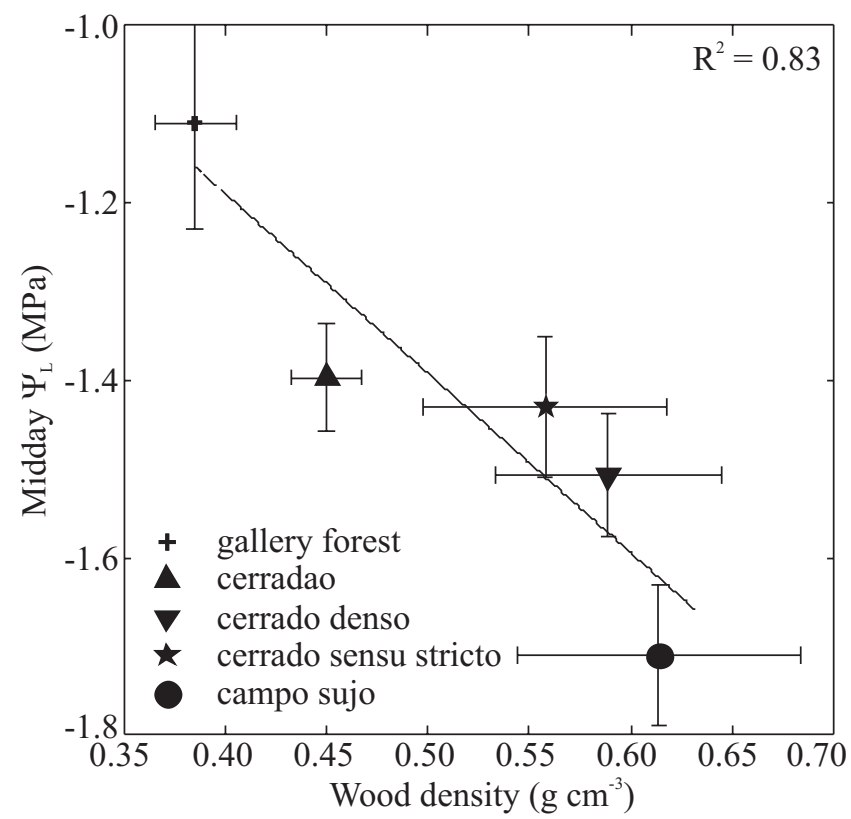

Figure 8. Midday leaf water potential in relation to weighted average wood density for sites differing in tree density (cerradão, cerrado denso, cerrado sensu stricto, campo sujo and gallery forest). Each point represents the mean value \pm SE of 10 to 16 species per site. For the gallery forest site only five dominant species were used. The line is the linear regression fitted to the data: $y=-0.38-2.02 x$; $\mathrm{P}<0.05$.

and leaf specific conductivity, mean stomatal conductance, mean SLA, and mean total leaf area per plant. It is not difficult to understand why variations in wood density should constrain plant hydraulics, because the physical properties of the active xylem tissue is the main pathway for water transport from the ultimate water source (soil water) to the various plant tissues, and in particular the leaves that are the main sink of water inside the tree. Wood density is a strong predictor of variations in a suite of traits related to stem water storage capacity, the efficiency of xylem water transport, regulation of leaf water status and avoidance of turgor loss (Bucci et al., 2004; Meinzer, 2003, Pratt and Black, 2006; Bhaskar et al., 2007; Pratt et al., 2007; Scholz et al., 2007). The widely reported inverse relationship between sapwood density and saturated water content implies that sapwood water storage diminishes with increasing wood density (Stratton et al., 2000; Bucci et al., 2004). These relationships are depicted in Figure 9. According to the flow diagram, wood density is directly related to 
hydraulic conductivity which in turn is related to leaf specific hydraulic conductivity. Low wood density is usually associated to high leaf specific hydraulic conductivity, and consequently to a relatively high efficiency of water transport per unit leaf surface area. Improving delivery of water to leaves and having higher stem hydraulic capacitance (that is also a function of low wood density), should result in smaller daily fluctuation in leaf water status. Species exhibiting isohydric behavior (Bucci et al., 2005) can allocate a smaller fraction of resources to osmoregulation and turgor maintenance (Figure 9), and therefore should be able to allocate additional resources for growth. Consistent with model predictions, sites with trees having lower wood density were characterized by higher leaf water potential at midday (Figure 8).

Enquist et al., (1999) developed an allometric model to predict growth rates of tropical trees using wood density as an independent variable and found that there was a trade-off between growth rate and allocation of biomass to tissue density, with species that allocate less biomass to stems (light woods) increasing in basal diameter faster than species that allocate more biomass to stems (dense woods). Trees in the upper portions of the topographic gradient in this study not only have lighter wood, but also higher total leaf surface area per individual and SLA, two traits that should promote faster growth (Figure 9). Specific leaf area is important to growth because it leads

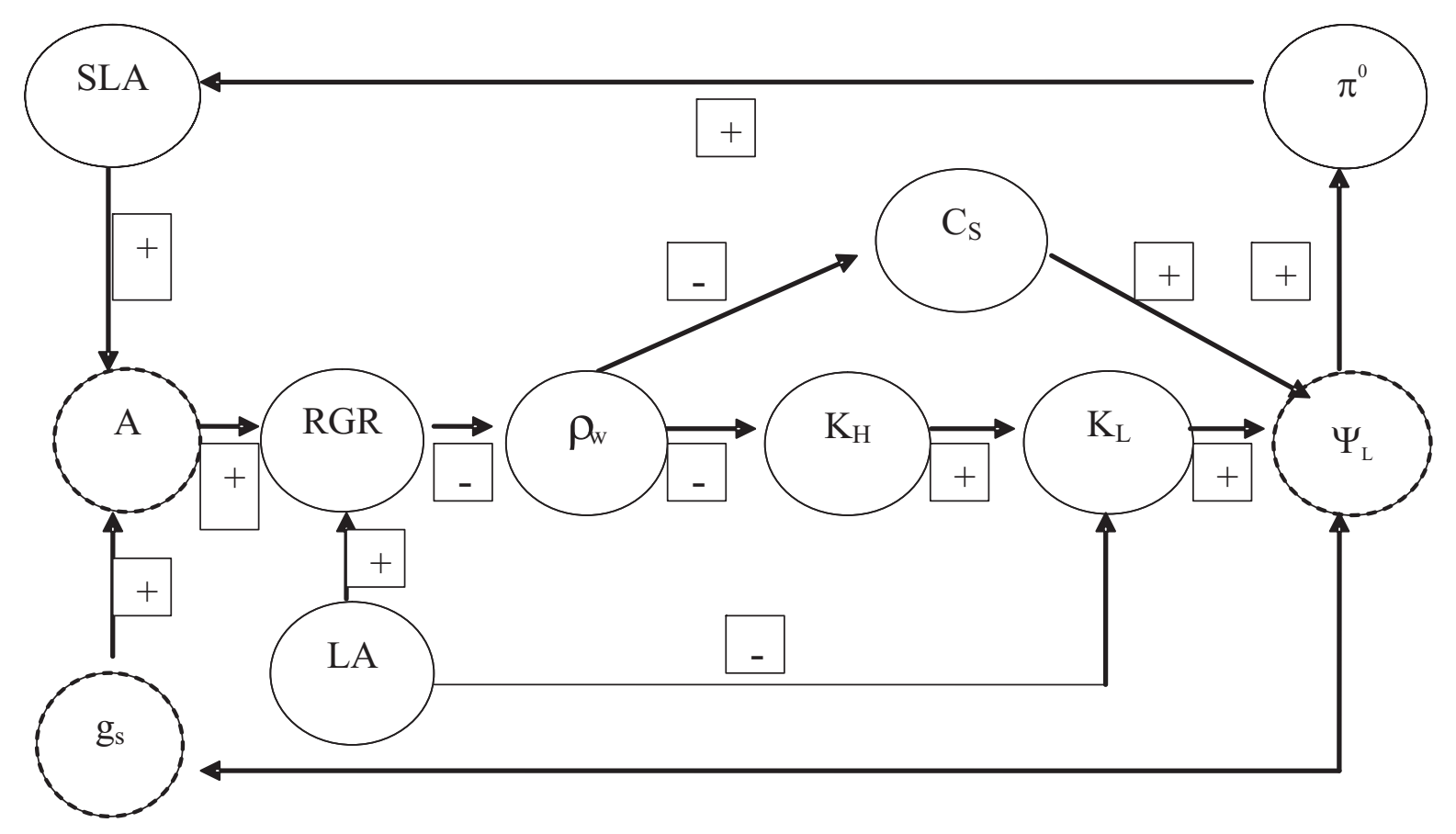

Figure 9. Flow diagram indicating cause and effect interactions among biophysical, morphological, and physiological traits of savanna trees that determine their hydraulic architecture and water relations. Circles with continuous lines (e.g. total leaf area per plant and wood density) are state variables depicting plant characteristics with slow response time (the time interval for a change, when changes in environmental conditions occur, is long (weeks to months). Circles with dashed lines (stomatal conductance, net $\mathrm{CO}_{2}$ assimilation, and leaf water potential), are variables with very rapid response time (the time interval for a change is short (e.g. seconds to hours). Arrows indicate the direction of cause and effect between two variables. RGR is relative growth rate, $r_{w}$ is sapwood density of the main stem, $\Psi_{L}$ is leaf water potential, $\pi^{\circ}$ is osmotic potential at the turgor loss point in leaf cells, LA is total leaf area per tree, SLA is specific leaf area, $\mathrm{K}_{\mathrm{H}}$ is stem hydraulic conductance, $\mathrm{K}_{\mathrm{L}}$ is leaf specific hydraulic conductivity, $\mathrm{A}$ is net $\mathrm{CO}_{2}$ assimilation, $\mathrm{C}_{\mathrm{S}}$ is stem water storage capacity and $g_{s}$ is stomatal conductance. The relationship between two variables in the diagram is positive (+) when both, the dependent and independent variables respond in the same direction (e.g. both increase), and is (-) when the dependent variable respond in a different way than the independent variable (e.g. the independent variable increase and the dependent variable decrease). 
to both a high leaf area displayed per unit mass invested (and hence efficient light capture) and high photosynthetic capacity (Reich et al., 1997, 1999; Shipley et al., 2005). Consistent with this general relationship, Franco et al., (2005) found that maximum net $\mathrm{CO}_{2}$ assimilation increased with SLA for evergreen and deciduous species in the same area of this research. Higher total leaf surface area per tree and higher assimilation rates (high stomatal conductance is a prerequisite for plants achieving high photosynthetic capacity) will result in higher growth rates under the assumption that species being compared allocate photoassimilates to leaves and non photosynthetic organs (e.g. stem and roots) in a similar fashion. Trees in the lower portion of the gradient have denser wood and a relatively small amount of leaf area per plant with low SLA. Consistent with these variations along the gradient, trees in high density stands (e.g. cerradão) are substantially taller and larger than trees in open savannas, which have relatively small tree sizes. The conceptual model in Figure 9 not only highlights the functional relationships between wood density and leaf water deficits and their potential impact on net $\mathrm{CO}_{2}$ assimilation and growth, but also suggests that increasing total leaf surface area per plant can promote higher growth rates. In our study we found that mean total leaf area per tree was inversely related to weighted average wood density: Increasing total leaf area and SLA is correlated to trees with lighter wood (Figure 4), and consequently higher growth rates. Species with high SLA have been shown to have higher rates of height growth (Reich et al., 1992). Leaf area and wood density are state variables depicting plant characteristics with slow response time (the time interval for a change, when changes in environmental conditions occur, is long (e.g. weeks to months).

Environmental determinants of changes in hydraulic architecture, water economy and growth rates: Which environmental factors determine the observed differences in wood density and associated hydraulic architecture traits that influence growth rates? Some of the factors hypothesized to be environmental determinants of physiognomic changes along the topographic gradients described at the beginning of this section may also help to explain the changes in morphofunctional traits. For example, water tables near the soil surface may slow down growth rates and therefore shift the pattern of carbon allocation to produce trees with heavier wood. Solid bedrock or laterite crusts, which can be found toward the lower end of the topographic gradient, may also limit root penetration to deeper horizons. Another potential limiting factor is nutrient content in the soil. In the Cerrado savannas, some authors have found variations in soil nutrient content along topographic gradients (e.g Moreira, 2000; Ruggiero et al., 2002). We have only observed that P content in the soil increased slightly from campo sujo to cerradão. Because $\mathrm{P}$ is considered one of the most limiting soil nutrients in the Cerrado (Kozovits et al., 2007), this small increase in soil P levels may by itself enhance growth rates of trees. However, we doubt that the observed changes in soil $\mathrm{P}$ are large enough to explain differences in growth rates and morphological and physiological changes along the topographic gradient. Soil $\mathrm{N}$ also appears also to be a limiting nutrient for Cerrado tree growth. Long term fertilizations with $\mathrm{N}$ resulted in substantial increases in stem diameter growth and increases in total leaf surface area per tree across all species in the fertilized plot (Bucci et al., 2006). It is possible that results of standard soil nutrient analyses, that do not show significant differences in nutrient concentrations along the topographic gradients, except $\mathrm{P}$ concentrations, do not reflect differences in soil ecosystem nutrients. Leaves of many deciduous and evergreen tree species senesce and drop during the dry season. Because of low water content in the upper soil layers during this period (Bucci et al., 2008; Scholz et al., 2008b), organic matter decomposition mainly occurs after the first large rainy events at the beginning of the wet season. Litter is rapidly decomposed and mineralizing nutrients are rapidly absorbed by roots or immobilized by microbial biomass (Garofalo, 2001). The amount of nutrient released and available for tree root absorption will be a function of the amount of litter produced by trees and herbaceous plants and the amount of nutrient intercepted and removed from the nutrient circulation pathway by the herbaceous layer. Short-circuiting of nutrients by savanna grasses (Luedemann, 2001) apparently makes nutrients released by decomposing litter less available to trees in open savannas where grass cover is substantially higher than in higher tree density physiognomies. The pattern observed in Figure 3 
suggests that nutrients also play a role in determining the functional changes in trees along tree density gradients. The functional relationship between weighted average wood density and mean leaf specific area has two end points: the gallery forest, which is a nutrient-rich ecosystem and the campo sujo, a nutrient-poor savanna. The high tree density cerradão site is located close to the gallery forest in this functional relationship, whereas the intermediate tree density sites are closer to the low tree density campo sujo site. Long-term fertilization of the cerrado sensu stricto sites with $\mathrm{N}$ or combined addition of $\mathrm{N}$ and $\mathrm{P}$ resulted in stand level value changes towards the nutrient rich end point of the relationship. Consistent with our hypothesis, Muller-Landau, (2004) found that wood density changed inversely with soil fertility in four Neotropical forests and that growth rate was lower in trees with denser wood.

\section{CONCLUSIONS}

We were able characterize plant and stand level variations in morpho-physiological traits of trees related to water economy along tree density gradients in the Cerrado. Gallery forest stands adjacent to the Cerrado sites studied, and fertilized plots of Cerrado were also included in the analysis to expand the axes of ecosystem variation. Consistent changes in stand level biophysical traits observed along a gradient of increasing tree density included a decrease in weighted wood density, increases in leaf surface area per plant, leaf specific hydraulic conductance, SLA and stomatal conductance. We predict that growth rates should also increase with increasing tree density. A conceptual model of biophysical, morphological and physiological trait interactions was developed in an attempt to explain determinants of hydraulic architecture and variations in water economy of Neotropical savanna woody plants. Consistent with model predictions, in sites where wood density was lower, trees were able to maintain higher leaf water potential at midday than in sites where wood density was higher. Higher leaf water potential was associated with higher stomatal conductance and consequently higher photosynthetic rates and growth. Variations in stand level physiological and morphological traits along the topographic gradient could not be explained by variations in single environmental factors.
We are hypothesizing that potential contributing factors are the relatively higher supply of $\mathrm{P}$ and $\mathrm{N}$ concentration in the upper portion of the gradient where tree density is high and waterlogging and laterite crusts in the lower part of the gradient where tree density is low.

Acknowledgements: This work was supported by grants from the National Science Foundation (USA) (grant \# 0296174 and grant \# 0322051), Inter-American Institute for Global Change Research, Conselho Nacional de Desenvolvimento Cientifico e Tecnologico (CNPq) and PRONEX (Brazil). We thank the Reserva Ecológica do IBGE for logistic support and to Thomas Weiber for providing useful field assistance.

\section{REFERENCES}

Bhaskar R, Valiente-Banuet A, Ackerly DD (2007) Evolution of hydraulic traits in closely related species pairs from mediterranean and nonmediterranean environments of North America. New Phytol. 176:718726.

Bucci SJ, Scholz FG, Goldstein G, Meinzer FC (2003) Dynamic diurnal changes in hydraulic specific conductivity in petiole of two savanna tree species: identifying factors and mechanisms contributing to the refilling of embolized vessels. Plant Cell Environ. 26:1633-1645.

Bucci SJ, Goldstein G, Meinzer FC, Scholz FG, Franco AC, Bustamante M (2004) Functional convergence in hydraulic architecture and water relations of tropical savanna trees: from leaf to whole plant. Tree Physiol. 24:891-899.

Bucci SJ, Goldstein G, Meinzer FC, Franco AC, Campanello P, Scholz FG (2005) Mechanisms contributing to seasonal homeostasis of minimum leaf water potential and predawn disequilibrium between soil and plants in Neotropical savanna trees. Trees 19:296-304.

Bucci SJ, Scholz FG, Goldstein G, Meinzer FC, Franco AC, Campanello PI, Villalobos-Vega R, Bustamante M, Miralles-Wilhelm F (2006) Nutrient availability constrains the hydraulic architecture and water relations of savanna trees. Plant Cell Environ. 29:2153-2167.

Bucci SJ, Scholz FG, Goldstein G, Hoffmann WA, Meinzer FC, Franco AC, Giambelluca T, Miralles-Wilhelm F (2008) Controls on stand transpiration and soil water 
utilization along a tree density gradient in a Neotropical Savanna. Agric. For. Meteorol. 148:839849.

Bustamante MMC, Martinelli LA, Silva DA, Camargo PB, Klink CA, Domingues TF, Santos RV (2004) ${ }^{15} \mathrm{~N}$ natural abundance in woody plants and soils of Central Brazilian savannas (Cerrado). Ecol. App. 14:201-214.

Bustamante MMC, Medina E, Asner GP, Nardotto GB, Garcia-Montiel DC (2006) Nitrogen cycling in tropical and temperate savannas. Biogeochemistry 79:209-237.

Choat B, Ball MC, Luly JG, Holtum JAM (2005) Hydraulic architecture of deciduous and evergreen dry rainforest tree species from north-eastern Australia. Trees 19:305-311.

Coutinho LM (1990) Fire in the ecology of the Brazilian cerrado. In: Goldammer JC (ed.). Fire in the Tropical Biota-Ecosystem Processes and Global Challenges. Ecol. Stud. 8:82-105.

Delitti WBC, Burger DM (2000) Carbon and mineral nutrient pools in a gallery forest at Mogi Guaçu River, Southeast Brazil. Ann. Sci. For. 57:39-48.

Domec JC, Scholz FG, Bucci SJ, Meinzer FC, Goldstein G, Villalobos-Vega R (2006) Diurnal and seasonal variation in root xylem embolism in neotropical savanna woody species: impact on stomatal control of plant water status. Plant Cell Environ. 29:26-35.

Duff GA, Myers BA, Williams RJ, Eamus D, O’Grady AO, Fordyce IR (1997) Seasonal patterns in soil moisture, vapor pressure deficit, tree canopy cover and predawn water potential in a northern Australian savanna. Aust. J. Bot. 45:211-224.

Eamus D, Cole SC (1997) Diurnal and seasonal comparisons of assimilation, phyllode conductance and water potential of three acacia and one eucalypt species in the wet-dry tropics of Australia. Aust. J. Bot. 45:275-290.

Enquist BJ, West GB, Brown JH (1999) Quarter-power allometric scaling in vascular plants: functional basis and ecological consequences. In Brown JH, West GB (eds.), Scaling in Biology, pp.167-199. Oxford University Press, Oxford.

Franco AC (1998) Seasonal patterns of gas exchange, water relations and growth of Roupala montana, an evergreen species. Plant Ecol. 136:69-76.

Franco AC, Bustamante M, Caldas LS, Goldstein G, Meinzer FC, Kozovits AR, Rundel P, Coradin VTR (2005) Leaf functional traits of Neotropical savanna trees in relation to seasonal water deficit. Trees 19:326-335.

Furley PA, Ratter JA (1988) Soil resources and plant communities of the central Brazilian Cerrado and their development. J. Biogeogr. 15:97-108.

Furley PA (1999) The nature and diversity of neotropical savanna vegetation with particular reference to the Brazilian cerrados. Global Ecol. Biogeogr. 8:223-241.

Jolly CA, Crawford RMM (1982) Variations in tolerance and metabolic responses to flooding in some tropical trees. J. Exp. Bot. 33:799-809.

Garofalo CR (2001) Efeitos do aumento da disponibilidade de nutrients na dinámica de nutrientes en plantas herbáceas e solo em uma área de cerrado stricto sensu. Brazil. University of Brasilia. M.S. thesis.

Goedert WJ (1987) Solos dos Cerrados-Tecnologias e estrategias de manejo. EMBRAPA-CPAC, Brasýlia, Brazil.

Gooldland R (1971) A Physiognomic analysis the Cerrado vegetation of Central Brazil. J. Ecol. 59:411-419.

Goodland R, Ferri MG (1979) Ecologia do Cerrado. Editora da Universidade de São Paulo, São Paulo, Brazil.

Haridasan M, Araujo GM (1988) Aluminum-accumulating species in two forest communities in the Cerrado region of Central Brazil. For. Ecol. Manage. 24:15-26.

Haridasan M (2000) Nutrição mineral das plantas nativas do Cerrado. Braz. J. Plant Physiol. 12:54-64.

Haridasan M (2008) Nutritional adaptations of native plants of the cerrado biome in acid soils. Braz. J. Plant Physiol. (in this Issue).

Haridasan M (2001) Nutrient cycling as a function of landscape and biotic characteristics in the cerrados of Central Brazil. In McClain ME, Victoria RL, Richey JR (eds.), The Biochemistry of the Amazon Basin. pp. 6883. Oxford University Press, New York.

Hoffmann WA (2000) Post-Establishment Seedling Success in the Brazilian Cerrado: A comparison of Savanna and Forest Species. Biotropica 32:62-69.

Hoffmann WA, Orthen B, Franco AC (2004) Constraints to seedling success of savanna and forest trees across the savanna-forest boundary. Oecologia 140:252-260.

Hoffmann WA, da Silva ER, Machado GC, Bucci SJ, Scholz FG, Goldstein G, Meinzer FC (2005a) Seasonal leaf dynamics across a tree density gradient in a Brazilian savanna. Oecologia 145:307-316. 
Hoffmann WA, Franco AC, Moreira MZ, Haridasan M (2005b) Specific leaf area explains differences in leaf traits between congeneric savanna and forest trees. Funct. Ecol. 19:932-940.

Kozovits AR, Bustamante MMC, Garofalo CR, Bucci SJ, Franco AC, Goldstein G, Meinzer FC (2007) Responses of plant-soil nutrient dynamics to increased nutrient availability in a central Brazilian savanna. Funct. Ecol. 21:1034-1043.

Luedemann G (2001) Efeito da adição de nutrientes ao solo sobre plantas rasteiras de um Cerrado stricto sensu. Brazil, University of Brasilia. M.S. Thesis.

McClenhan MC, Macinnis-Ng C, Eamus D (2004) Hydraulic architecture and water relations of several species at diverse sites around Sydney. Aust. J. Bot. 52:509-518.

Meinzer FC, Goldstein G, Franco AC, Bustamante M, Igler E, Jackson P, Caldas L, Rundel PW (1999) Atmospheric and hydraulic limitations on transpiration in Brazilian Cerrado woody species. Funct. Ecol. 13:273-282.

Meinzer FC (2003) Functional convergence in plants responses to the environment. Oecologia 134:1-11.

Meinzer FC, James SA, Goldstein G, Woodruff D (2003) Whole-tree water transport scales with sapwood capacitance in tropical forest canopy trees. Plant Cell Environ. 26:1147-1155.

Moreira AG (2000) Effects of fire protection on savanna structure in Central Brazil. Journal of Biogeography 27:1021-1029.

Muller-Landau HC (2004) Interspecific and inter-site variation in wood specific gravity of 13 tropical trees. Biotropica 36:20-32.

Myers BA, Duff GA, Eamus D, Fordyce IR, O’Grady AP, Williams RJ (1997). Seasonal variation in water relations of trees of differing leaf phenology in a wetdry tropical savanna near Darwin, Northern Australia. Aust. J. Bot. 45:225-240.

Oliveira-Filho AT, Shepherd GD, Martins FR, Stubblebine WH (1989) Environmental factors affecting physiognomic and floristic variation in an area of cerrado in Central Brazil. J. Trop.Ecol. 5:413-431.

Oliveira PE, Gibbs PE (2000) Reproductive biology of woody plants in a cerrado community of Central Brazil. Flora 195:311-329.

Pinto AS, Bustamante MMC, Kisselle K, Burke R, Zepp R Viana LT, Varella RF, Molina M (2002) Soil emissions of
N2O, NO and CO2 in Brazilian Savannas: effects of vegetation type, seasonality and prescribed fires. Journal of Geophysical Research 107:8089-8095.

Prado CHBAP, Wenhi Z, Rojas MHC (2004) Seasonal leaf exchange and water potential in a woody cerrado species community. Braz. J. Plant Physiol. 16:7-16.

Pratt RB, Black RA (2006) Do invasive trees have a hydraulic advantage over native trees? Biological Invasions 8:1331-1341.

Pratt RB, Jacobsen AL, Ewers FW, Davis SD (2007) Relationships among xylem transport, biomechanics, and storage in stems and roots of nine Rhamnaceae species of the California chaparral. New Phytol 174:787-798.

Ratter JA, Richards PW, Argent G, Gifford DR (1978) Observations on the forests of some mesotrophic soils in central Brazil. Revta brasil Bot 1:47-58.

Ratter JA, Bridgewater S, Atkinson R, Ribeiro JF (1996) Analysis of the floristic composition of the Brazilian cerrado vegetation II: comparison of the woody vegetation of 98 areas. Edinb. J. Bot. 53:153-180.

Reich PB, Walters MB, Ellsworth DS (1992) Leaf life-span in relation to leaf, plant, and stand characteristics among diverse ecosystems. Ecol. Monogr. 62:365-392.

Reich PB, Walters MA, Ellsworth DS (1997) From tropics to tundra: global convergence in plant functioning. Proc. Natl. Acad. Sci. USA. 94:13730-13734.

Reich PB, Ellsworth D.S, Walters MB, Vose JM, Gresham C, Volin JC, Bowman WD (1999) Generality of leaf trait relationships: a test across sib biomes. Ecology. 80:1955-1969.

Ribeiro JP, Walter BMT (1998) Fitofisionomias do Bioma Cerrado. In: Sano SM, Almeida SP, eds. Pp 89-166, Cerrado, ambiente e flora. Planaltina: EMBRAPA.

Ruggiero PGC, Batalha MA. Pivello VR, Meirelles ST (2002) Soil-vegetation relationships in cerrado (Brazilian savanna) and semideciduous forest, Southeastern Brazil. Plant Ecol. 160:1-16.

Ruggiero PGC, Pivello VR, Sparovek G, Teramoto E, Pires Neto AG (2006) Relação entre solo, vegetação e topografia em área de cerrado (Parque Estadual de Vassununga, SP): como se expressa em mapeamentos? Acta Bot. Bras. 20:383-394.

Santiago LS, Goldstein G, Meinzer FM, Fisher JB, Machado K, Woodruff D, Jones T (2004) Leaf photosynthetic traits scale with hydraulic 
conductivity and wood density in Panamanian forest canopy trees. Oecologia 140:543-550.

Saraceno MI (2006) Efeitos da fertilizacao a longo prazo no metabolismo fotossintetico, nas caracteristicas foliares e no crescimento em arvores do cerrado. Brasilia, University of Brasilia. M.S. Thesis.

Sarmiento G (1983) The savannas of tropical America. In: Bouliere F (ed), Tropical savannas. Ecosystem of the World/Tropical savannas, pp.245-248. Elsevier Scientific Pub. New York.

Sarmiento G (1984) The ecology of neotropical savannas. Harvard University, Cambridge,235p.

Scholz FG, Bucci SG, Goldstein G, Meinzer FC, Franco AC, Miralles-Wilhelm F (2007) Biophysical properties and functional significance of stem water storage tissues in Neotropical savanna trees. Plant Cell Environ. 30:236-248.

Scholz FG, Bucci SJ, Goldstein G, Meinzer FC, Franco AC, Miralles-Wilhelm F (2008a) Temporal dynamics of stem expansion and contraction in savanna trees: withdrawal and recharge of stored water. Tree Physiol. 28:469-480.

Scholz FG, Bucci SJ, Goldstein G, Moreira MZ, Meinzer FC, Domec J-C, Villalobos-Vega R, Franco AC, Miralles-Wilhelm F (2008b) Biophysical and life history determinants of hydraulic lift in Neotropical savanna trees. Funct. Ecol. 22:773-786.

Shipley B, Vile D, Garnier E, Wright IJ, Poorter H (2005) Functional linkages between leaf traits and net photosynthetic rate: reconciling empirical and mechanistic models. Funct. Ecol. 19:602-615.

Silva Junior MC (2005) Fitossociologia e estrutura diametrica na mata em galeria do Pitoco na reserva ecologica do IBGE, DF. Cerne Labras 11:147-158.

Silva LCR, Sternberg L, Haridasan M, .Hoffmann WA, Miralles-Wilhelm F, Franco AC (2008) Expansion of gallery forest into central Brazilian savannas. Global Change Biology 14:2108-2118.

Stratton L, Goldstein G, Meinzer FC (2000) Stem water storage capacity and efficiency of water transport: their functional significance in a Hawaiian dry forest. Plant Cell Environ. 23:99-106.

Thomas DS, Eamus D (2002) Seasonal patterns of xylem sap $\mathrm{pH}$, xylem abscisic acid concentration, leaf water potential and stomatal conductance of six evergreen and deciduous Australian savanna tree species. Aust J. Bot. 50:229-236.

Tyree MT, Hammel HT (1972) The measurement of the turgor pressure and water relations of plants by the pressure bomb technique. J. Exp. Bot. 23:267-282. 